\section{Pengaruh Financial Leverage, Roi, Roe, Reputasi Auditor, dan Reputasi Underwriter terhadap Tingkat Underpricing Saham pada Saat IPO di BEI}

\author{
Hestytia Nirmala Assari, Ahmad Juanda, Eny Suprapti \\ Program Studi Akuntansi Fakultas Ekonomi dan Bisnis \\ Universitas Muhammadiyah Malang. \\ Jl. Raya Tlogomas No. 246 Malang 65144
}

\title{
ABSTRACT
}

The purpose of this research is to prove that financial leverage, ROI, ROE, auditor reputation and underwriter reputation have an effect on underpricing during IPO. The type of this research is associative, the population of this study is a company that conducts initial public offering (IPO) in BEI year 2007-2012. Sampling was done using purposive sampling. Types of data used are qualitative and quantitative data. The results of this study indicate that the variables of financial leverage (DER), ROI, ROE, Reputation Auditor, and Reputation Underwriter simultaneously affect the level of underpricing of stocks as evidenced by the F-test results of 3.100 with a significance level smaller than 0, 05 which is 0,014. While the test results partially (Test T) shows that only the underwriter reputation only variables that have a significant effect on the level of underpricing the stock.

Keywords: financial leverage, ROI, ROE, auditor reputation, underwriter reputation, underpricing

\section{PENDAHULUAN}

Fenomena underpricing di dalam IPO dikenal hampir diseluruh dunia. Dari beberapa penelitian menunjukan bahwa underpricing terjadi hampir pada setiap pasar efek di seluruh dunia seperti Amerika Serikat (Bavers et al, 1988), Korea (Kim et al, 1993), Taiwan (Liaw,Lie,Wei,2000), serta Jepang (Kutsuna dan Smith,2000) (Yolana dan Martani, 2005). Hal ini juga terjadi pada pasar efek di Indonesia. Penelitian Daljono (2000) menunjukkan bahwa penawaran saham perdana pada perusahaan-perusahaan privat maupun BUMN di Indonesia umumnya mengalami underpricing.

Bagi investor, IPO menarik perhatian karena selama ini harga pada saat IPO cenderung underpriced sehingga pembelian saham pada saat IPO merupakan investasi yang menguntungkan. Initial Public Offering (IPO) merupakan salah satu sumber pendanaan bagi perusahaan (Asnawi dan Wijaya, 2005:151). Harga saham yang ditawarkan pada saat melakukan IPO merupakan faktor yang penting dalam menentukan berapa besar jumlah dana yang diperoleh emiten. Jumlah dana yang diperoleh emiten adalah jumlah perkalian antara jumlah lembar saham yang ditawarkan dengan harga per saham. Apabila harga saham saat IPO secara signifikan lebih rendah dibandingkan dengan harga yang terjadi di pasar sekunder pada hari pertama, maka terjadi fenomena harga rendah yang disebut underpricing (Yasa,2008).

Adapun berbagai teori yang dikemukakan dan diteliti oleh para ahli untuk menjelaskan penyebab terjadinya fenomena underpricing diantaranya: Baron (1982), Rock (1986), dan Beatty (1989) menjelaskan terjadinya underpricing karena

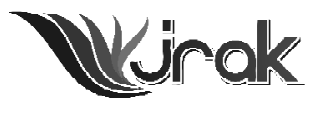

Jurnal Reviu Akuntansi dan Keuangan ISSN: 2088-0685 Vol.4 No. 1, April 2014 Pp 545-554 
Pengaruh Financial Leverage... adanya information asymmetry antara perusahaan emiten dengan penjamin emisi dan antara informed investor dengan uninformed investor. Informasi yang disajikan dalam prospektus memberikan gambaran perusahaan emiten yang berguna bagi investor untuk membuat keputusan.

Menurut Beatty (1989), kondisi underpricing menimbulkan dampak positif bagi investor karena mereka menerima initial return yaitu keuntungan yang diperoleh pemegang saham karena perbedaan harga saham yang dibeli di pasar perdana saat IPO dengan harga jual yang bersangkutan di hari pertama di pasar sekunder. Menurut Ardiansyah (2003), faktor-faktor yang mempengaruhi gejala underpricing diantaranya: informasi keuangan (ROE, Financial Leverage, Current Ratio, EPS, Size, Proceed, Pertumbuhan Laba) dan informasi non keuangan (Umur Perusahaan, Reputasi Auditor, Penjamin Emisi, Jenis Industri).

Hal ini didukung oleh beberapa penelitian seperti Daljono (2000) membuktikan bahwa financial leverage secara parsial berpengaruh signifikan positif terhadap tingkat underpricing sedangkan Sari (2011), Kristiantari (2012), dan Wahyuni (2012) membuktikan bahwa financial leverage tidak berpengaruh signifikan terhadap tingkat underpricing saham. Daljono (2000), Yolana dan Martani (2005) dan Johnson (2012) membuktikan bahwa reputasi underwriter tidak berpengaruh signifikan terhadap tingkat underpricing saham namun Beatty (1989), Yasa (2008), Murdiyani (2009) dan Kristiantari (2012) membuktikan bahwa reputasi underwriter berpengaruh signifikan (negatif) terhadap tingkat underpricing saham. Daljono (2000) dan Kristiantari (2012) membuktikan bahwa reputasi auditor secara parsial tidak berpengaruh signifikan terhadap tingkat underpricing tetapi Yasa (2008), Murdiyani (2009) dan Johnson (2012) membuktikan bahwa reputasi auditor berpengaruh terhadap tingkat underpricing saham. Abdullah (2000), Johnson (2012), dan Wahyuni (2012) membuktikan bahwa ROE tidak berpengaruh signifikan terhadap tingkat underpricing saham secara parsial sedangkan Yolana dan Martani (2005) membuktikan adanya pengaruh signifikan antara ROE terhadap tingkat underpricing. Yasa (2008) dan Sari (2011) membuktikan bahwa ROI juga berpengaruh signifikan negatif terhadap underpricing.

Meskipun studi tentang underpricing telah banyak dilakukan, namun penelitian di bidang ini masih dianggap masalah yang menarik untuk diteliti karena adanya ketidakkonsistenan hasil penelitian, maka peneliti termotivasi meneliti kembali untuk memperoleh bukti empiris yang dapat memberikan manfaat bagi pihak-pihak yang berkepentingan. Dari uraian diatas, peneliti tertarik melakukan penelitian dengan judul "Pengaruh Financial Leverage, ROI, ROE, Reputasi Auditor, dan Reputasi Underwriter terhadap tingkat Underpricing Saham pada saat IPO di BEI".

Tujuan penelitian ini adalah yang pertama Untuk membuktikan bahwa Financial Leverage berpengaruh terhadap underpricing saat IPO. Yang kedua Untuk membuktikan bahwa Return on Investment (ROI) berpengaruh terhadap underpricing saat IPO. Yang ketiga Untuk membuktikan bahwa Return on Equity (ROE) berpengaruh terhadap underpricing saat IPO. Yang keempat Untuk membuktikan bahwa Reputasi Auditor berpengaruh terhadap underpricing saat IPO. Yang kelima Untuk membuktikan bahwa Reputasi Underwriter berpengaruh terhadap underpricing saat IPO.

Berdasarkan perumusan masalah, tujuan penelitian dan landasan teori, maka hipotesis yang diajukan adalah sebagai berikut:

$\mathrm{H}_{1}$ : Financial Leverage berpengaruh signifikan terhadap tingkat underpricing saham

$\mathrm{H}_{2}$ : Return on Invesment (ROI) berpengaruh siginifikan tingkat terhadap underpricing saham

$\mathrm{H}_{3}$ : Return on Equity (ROE) berpengaruh signifikan terhadap tingkat underpricing saham 

saham

\section{METODE PENELITIAN}

Jenis penelitian yang dilakukan adalah penelitian asosiatif. Populasi penelitian ini adalah seluruh perusahaan yang melakukan penawaran umum perdana (IPO) di Bursa Efek Indonesia (BEI) tahun 2007 sampai 2012. Pengambilan sampel dilakukan berdasarkan metode purposive samplin.g. Data dalam penelitian ini dikumpulkan dengan cara dokumentasi dari berbagai macam sumber. Teknik analisis data yang akan dipergunakan dalam penelitian ini adalah uji statistic parametik dengan menggunakan alat bantu SPSS (Statistical Product and Service Solution) versi 16.0. Analisis regresi yang digunakan untuk menguji penelitian ini adalah dengan menggunakan regresi linear berganda sebab terdapat variabel bebas yang lebih dari satu. Menggunakan statistik deskriptif, uji normalitas, uji asumsi klasik meliputi uji autokorelasi, uji multikolienaritas, uji heteroskedestisitas dan analisis regresi linier berganda.

\section{HASIL DAN PEMBAHASAN}

Statistika Deskriptif

\begin{tabular}{lrrrrr}
\hline & N & Minimu & Maximu & Mean & \multicolumn{1}{c}{ Std. } \\
\hline Reputasi_underwriter & 72 & 0 & 1 & .32 & .470 \\
Reputasi_auditor & 72 & 0 & 1 & .32 & .470 \\
Tingkat_under pricing & 72 & .0028 & 1.1250 & .317475 & .2601950 \\
sqrt_DER & 72 & .03 & 3.08 & 1.4017 & .67489 \\
sqrt_R0E & 72 & .03 & .63 & .3677 & .14712 \\
sqrt_ROI & 72 & .02 & .45 & .2104 & .10248 \\
Valid N (listwise) & 72 & & & & \\
\hline
\end{tabular}

Sumber: Data diolah SPSS

Berdasarkan statisktika deskriptif diatas, rata-rata tingkat underpricing dari sampel penelitian ini adalah $31,74 \%$. Tingkat underpricing yang paling rendah yaitu sebesar $0,28 \%$. Underpricing yang paling tinggi yaitu sebesar $112,50 \%$. Ditinjau dari financial leverage (DER), DER perusahaan yang minimum sebesar 3\% yaitu PT. Rata-rata financial leverage (DER) dari sampel dalam penelitian ini sebesar $140,17 \%$. Ditinjau dari profitabilitas (ROI), ROI perusahaan yang minimum sebesar $2 \%$ ROI perusahaan yang maksimum diperoleh sebesar $45 \%$. Sedangkan rata-rata ROI dari sampel dalam penelitian ini sebesar $21,04 \%$.

\begin{tabular}{lcccc}
\hline & \multicolumn{2}{c}{ Skewness } & \multicolumn{2}{c}{ Kurtosis } \\
\cline { 2 - 5 } & Statistic & Std. Error & Statistic & Std. Error \\
\hline Sqrt_TingkatUnderpricing & 0,083 & 0,283 & $-1,051$ & 0,559 \\
Sqrt_DER & 0,226 & 0,283 & $-0,262$ & 0,559 \\
Sqrt_ROI & 0,312 & 0,283 & $-0,489$ & 0,559 \\
Sqrt_ROE & $-0,200$ & 0,283 & $-0,155$ & 0,559 \\
Reputasi Auditor & 0,791 & 0,283 & $-1,414$ & 0,559 \\
Reputasi Underwriter & 0,791 & 0,283 & $-1,414$ & 0,559 \\
\hline
\end{tabular}

Tabel 4.1

Statistika Deskriptif

Sumber: Data diolah SPSS 


\section{Pengaruh Financial}

Leverage...

Tabel 4.3

Uji Normalitas

Tabel 4.4

Uji Autokorelasi

Variabel $\left(\mathrm{Xi}, \mathrm{X}_{2}, \mathrm{X}_{3}\right.$,

$\left.\mathrm{X}_{4}, \mathrm{X}_{5}, \mathrm{X}_{6}\right)$ terhadap $\mathrm{Y}$

Sebelum

transformasi

Tabel 4.5

Uji Autokorelasi

Variabel (Xi, $\mathrm{X}_{2}, \mathrm{X}_{3}$, $\mathrm{X}_{4}, \mathrm{X}_{5}, \mathrm{X}_{6}$ ) terhadap $\mathrm{Y}$ setelah transformasi

Tabel 4.6

Hasil VIF dan

Tolerance sebelum transformasi
Tabel 4.8

Hasil VIF dan

Tolerance setelah transformasi

\begin{tabular}{lcc}
\hline & Skewness & Kurtosis \\
\hline Sqrt_TingkatUnderpricing & 0,293 & $-1,880$ \\
Sqrt_DER & 0,798 & $-0,468$ \\
Sqrt_ROI & 1,102 & $-0,874$ \\
Sqrt_ROE & $-0,706$ & $-0,277$ \\
Reputasi Auditor & 0,224 & $-0,790$ \\
Reputasi Underwriter & 0,224 & $-0,790$ \\
\hline
\end{tabular}

Berdasarkan hasil dari perhitungan atas nilai skewness dan kurtosis, menghasilkan perhitungan nilainya di antara -2 dan 2 , maka dengan begitu dapat disimpulkan data penelitian terdistribusi secara normal.

Uji autokorelasi

\begin{tabular}{rrrrrrrl}
\hline No & & $\mathrm{dL}$ & $\mathrm{dU}$ & $\mathbf{4}-\mathrm{dU}$ & $\mathbf{4}-\mathrm{dl}$ & $\mathrm{DW}$ & Interprestasi \\
\hline 1 & Nilai & 1,3821 & 1,5969 & 2,4031 & 2,6179 & 1,576 & $\begin{array}{l}\text { Terjadi } \\
\text { autokorelasi }\end{array}$ \\
\hline
\end{tabular}

Sumber: Data diolah SPSS Tabel 4.5 menunjukkan bahwa terdapatnya autokorelasi tidak dapat disimpulkan karena nilai Durbin-Watson berada antara dL dan dU yaitu $(1,3821<1,576<1,5969)$.

Autokrelasi bisa diatasi dengan melakukan transformasi data dan menambah data observasi. Data observasi yang semula hanya 3 tahun ditambah sehinnga menjadi 6 tahun dan dilakukan

transformasi data ke bentuk square root. Hasil uji autokorelasi setelah melakukan transformasi dapat dilihat pada tabel 4.6.

\begin{tabular}{cccccccc}
\hline No & & $\mathrm{dL}$ & $\mathrm{dU}$ & $\mathbf{4}-\mathrm{dU}$ & $\mathbf{4}-\mathrm{dl}$ & $\mathrm{DW}$ & Interprestasi \\
\hline 1 & \multirow{2}{*}{ Nilai } & 1,5611 & 1,6751 & 2,3249 & 2,4389 & 1,685 & $\begin{array}{l}\text { Tidak ada auto } \\
\text { korelasi }\end{array}$ \\
\hline
\end{tabular}

Sumber: Data diolah SPSS Berdasarkan hasil uji Durbin watson dalam model regresi menunjukkan hasil sebesar 1,685 nilai ini berada pada daerah antara $d U$ dan 4-dU. Nilai $d U$ sebesar $1,6751, d L$ 1,5611 , serta $4-d U$ yaitu 2,3249 . Dengan begitu nilai DW berada pada daerah tanpa autokorelasi.

Uji Multikolienaritas

\begin{tabular}{cccc}
\hline No & Variabel & Nilai VIF & Nilai TOL \\
\hline 1 & DER & 1,703 & 0,587 \\
2 & ROI & 10,407 & 0,096 \\
3 & ROE & 10,010 & 0,100 \\
4 & Reputasi Auditor & 1,136 & 0,880 \\
5 & Reputasi Underwriter & 1,116 & 0,896 \\
\hline
\end{tabular}

Sumber: Data diolah SPSS

Berdasarkan hasil analisis pada tabel 4.7 terlihat angka untuk variabel ROI dan ROE angka VIF lebih besar dari sepuluh $(>10)$ dan nilai tolerance pada variabel ROI lebih kecil dari 0,1 yaitu sebesar 0,096. Hal ini menunjukkan adanya problem multikolinieritas dalam model regresi. Langkah untuk menghilangkan multikolinieritas adalah dengan mengeluarkan salah satu variabel atau melakukan transformasi data. Pada tabel 4.8 disajikan tabel hasil VIF dan tolerance setelah dilakukan transformasi data dalam bentuk Square Root (sqrt).

\begin{tabular}{cccc}
\hline No & Variabel & Nilai VIF & Nilai TOL \\
\hline 1 & DER & 1,822 & 0,549 \\
2 & ROI & 3,040 & 0,329 \\
3 & ROE & 3,019 & 0,331 \\
4 & Reputasi Auditor & 1,109 & 0,902 \\
5 & Reputasi Underwriter & 1,214 & 0,824 \\
\hline
\end{tabular}

Sumber: Data diolah SPSS 
Berdasarkan hasil analisis pada tabel 4.6 terlihat bahwa nilai tolerance terletak antara 0,329 sampai 0,902 dengan begitu nilai tolerance $>0,1$ serta nilai VIF yang terletak antara 1,109 sampai 3,040 yang berarti $<10$, melihat dari hasil uji nilai tolerance dan VIF menunjukkan tidak adanya multikolinearitas pada model regresi.

Uji Heteroskedestisitas

Dependent Variable: sqrt_Tingkatunderpricing

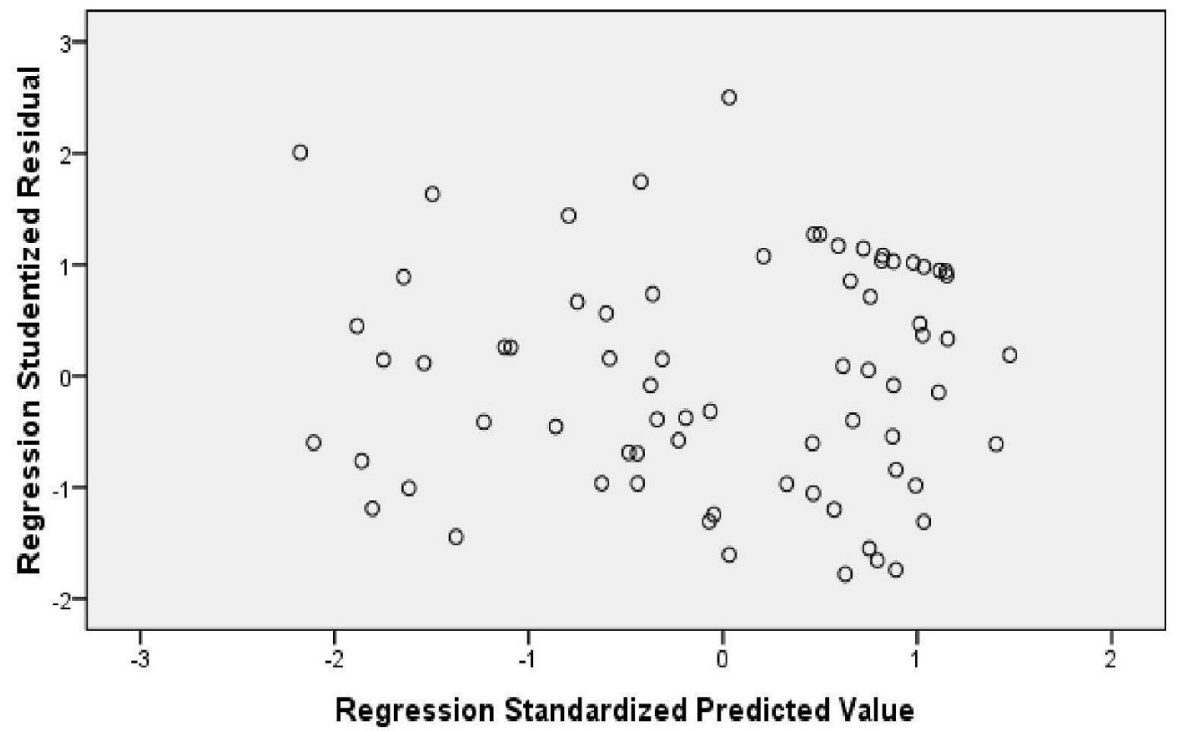

Gambar 4.1 menunjukkan bahwa berdasarkan hasil plot titik-titik menyebar tidak beraturan dalam arti tidak membentuk suatu pola tertentu baik di atas maupun di bawah 0 sumbu Y. sehingga dapat disimpulkan model regresi ini tidak terdapat gejala heterokedastisitas. Selain melihat scatter plot dilakukan pula uji Glejser untuk mendeteksi adanya gejala. Berdasarkan hasil pengujian dengan menggunakan SPSS didapatkan hasil sebagai berikut:

\begin{tabular}{ccccrc}
\hline & \multicolumn{2}{c}{$\begin{array}{c}\text { Unstandardized } \\
\text { Coefficients }\end{array}$} & $\begin{array}{c}\text { Standardized } \\
\text { Coefficients }\end{array}$ & & \\
\cline { 2 - 5 } Model & \multicolumn{1}{c}{ B } & Std. & Beta & t & Sia. \\
\hline 1 (Constant) & .195 & .048 & & 4.086 & .000 \\
Reputasi_unde & -.043 & .032 & -.173 & -1.347 & .183 \\
Reputasi_auditor & .026 & .030 & .107 & .874 & .385 \\
sqrt_DER & -.044 & .027 & -.255 & -1.627 & .189 \\
sqrt_ROE & .367 & .159 & .465 & 2.302 & .025 \\
sqrt_ROI & -.365 & .230 & -.322 & -1.590 & .117 \\
\hline
\end{tabular}

Tabel 4.10

Hasil Uji Glejser

a. Dependent Variable: glejser

Sumber: Data diolah SPSS Berdasarkan hasil uji heteroskedastisitas menggunakan uji Glejser diperoleh hasil nilai Sig > 0,05, tetapi terdapat satu variabel yaitu ROE yang signifikansinya kurang dari 0,05. Jadi dapat dikatakan bahwa sebenarnya kejadian heteroskedastisitas sangat kecil, karena 4 variabel bebas lainnya memiliki pengaruh yang siginifikan. Dengan demikian masih dapat dibenarkan asumsi ini terpenuhi homoskedastisitas. 


\section{Pengaruh Financial}

Leverage...

550

Tabel 4.10

Hasil Uji Regresi

Linear Berganda
Analisis Regresi Linear Berganda

Coefficients"

\begin{tabular}{ccccrc}
\hline & \multicolumn{2}{c}{$\begin{array}{c}\text { Unstandardized } \\
\text { Coefficients }\end{array}$} & $\begin{array}{c}\text { Standardized } \\
\text { Coefficients }\end{array}$ & & \multicolumn{1}{c}{ Sid. } \\
\cline { 2 - 4 } Model & B & Std. Error & Beta & & S \\
\cline { 2 - 3 } l (Constant) & .624 & .096 & & 6.519 & .000 \\
Reputasi_underwr & -.151 & .064 & -.289 & -2.365 & .021 \\
Reputasi_auditor & -.110 & .061 & -.210 & -1.803 & .076 \\
sqrt_DER & -.002 & .054 & -.007 & -.044 & .965 \\
sqrt_ROE & -.259 & .320 & -.155 & -.807 & .422 \\
sqrt_ROI & .312 & .462 & .131 & .676 & .501 \\
\hline
\end{tabular}

a. DependentVariable: sqrt_Tingkatunderpricing

Sumber : Data diolah SPSS Adapun persamaan regresinya adalah sebagai berikut: Sqrt_TingkatUnderpricing $=0,624-0,002$ Sqrt_DER +0.312 Sqrt_ROI $-0,259$

Sqrt_ROE - 0,110 ReputasiAuditor - 0,151 Reputasi Underwriter + e

Langkah selanjutnya yaitu mengembalikan model regresi dari bentuk Square Root ke bentuk awal, adapun persamaan regresinya sebagai berikut: TingkatUnderpricing $=0,389-0,000002$ DER + 0,097 ROI - 0,067 ROE -0,0121 ReputasiAuditor - 0,022 ReputasiUnderwriter + e

Interprestasi dari koefisien regresi dapat dijelaskan sebagai berikut:

a. Konstanta sebesar 0,389 mempunyai arti jika variabel independen yang terdiri dari financial leverage (DER), ROI, ROE, reputasi auditor, dan reputasi underwriter nilainya nol maka tingkat underpricing akan sebesar 0,389\%.

b. Koefisien regresi DER sebesar -0,000002 dengan signifikansi 96,5\% menunjukkan apabila DER naik sebesar 1\%, maka tingkat underpricing akan menurun sebesar $0,0002 \%$ dengan asumsi semua variabel independen lain dalam kondisi stabil.

c. Koefisien regresi ROI sebesar 0,097 dengan signifikansi 50,1\% menunjukkan apabila ROI naik sebesar 1\%, maka tingkat underpricing akan meningkat sebesar 9,7\% dengan asumsi semua variabel independen lain dalam kondisi stabil.

d. Koefisien regresi ROE sebesar -0,067 dengan signifikansi 42,2\% menunjukkan apabila ROE naik sebesar 1\%, maka tingkat underpricing akan menurun sebesar $6,7 \%$ dengan asumsi semua variabel independen lain dalam kondisi stabil.

e. Koefisien regresi reputasi auditor sebesar -0,0121 dengan signifikansi 7,6\% menunjukkan apabila reputasi auditor naik sebesar 1 satuan, maka tingkat underpricing akan menurun sebesar 1,21\% dengan asumsi semua variabel independen lain dalam kondisi stabil. Pengaruh negatif ini akan membuat perusahaan lebih memilih menggunakan jasa auditor yang tergolong The Big Four agar tingkat underpricing dapat menjadi semakin kecil.

f. Koefisien regresi reputasi underwriter sebesar -0,022 dengan signifikansi $2,1 \%$ menunjukkan apabila reputasi underwriter naik sebesar 1 satuan, maka tingkat underpricing akan menurun sebesar $2,2 \%$ dengan asumsi semua variabel independen lain dalam kondisi stabil. Sehingga perusahaan yang ingin menekan tingkat underpricing disarankan memakai underwriter yang berpengalaman dan termasuk Top 5 Underwriter. 
Model Summary ${ }^{1 *}$

\begin{tabular}{cccccc}
\hline Mode 1 & $\mathrm{R}$ & R Square & $\begin{array}{c}\text { Adjusted R } \\
\text { Square }\end{array}$ & $\begin{array}{c}\text { Std. Error of the } \\
\text { Estimate }\end{array}$ & $\begin{array}{c}\text { Durbin- } \\
\text { Watson }\end{array}$ \\
\hline $\mathrm{l}$ & $.436=$ & .190 & .129 & .22858 & 1.685 \\
\hline
\end{tabular}

a. Predictors: (Constant), sqrt_ROI, Reputasi_auditor, sqrt_DER, Reputasi_underwriter, sqrt_ROE b. DependentVariable: sqrt_Tingkatunderpricing

Sumber: Data diolah SPSS Berdasarkan hasil analisis regresi berganda diperoleh nilai koefisien determinasi $(R$ ) yang diambil dari Adjusted $R$, diperoleh nilai sebesar 0,129 atau 12,9\%. Nilai ini menunjukkan bahwa kemampuan variabel bebas (financial leverage (DER), ROI, ROE, Reputasi Auditor, dan Reputasi Underwriter) dalam mempengaruhi variabel terikat (tingkat underpricing saham) sebesar 12,9\% sedangkan $87,1 \%$ dipengaruhi oleh variabel lain yang tidak terdapat dalam regresi.

\begin{tabular}{|c|c|c|c|c|c|}
\hline Model & $\begin{array}{l}\text { Sunn of } \\
\text { Squares }\end{array}$ & $\mathrm{df}$ & Mean Square & F & Siq. \\
\hline l Regression & .810 & 5 & .162 & 3.100 & $.014=$ \\
\hline Residual & 3.448 & 66 & .052 & & \\
\hline Total & 4.258 & 71 & & & \\
\hline
\end{tabular}

a. Predictors: (Constant), sqrt_ROI, Reputasi_auditor, sqrt_DER, Reputasi_underwriter, sqrt_ROE

b. Dependent Variable: sqrt_Tingkatunderpricing

Sumber: Data diolah SPSS Dari hasil uji ANOVA didapat F-hitung sebesar 3,100 dengan tingkat signifikansi 0,014. Karena tingkat signifikansi 0,014 lebih kecil dari 0,05 atau 5\%, hal ini berarti bahwa model yang digunakan adalah layak. Model regresi dapat digunakan untuk memprediksi underpricing atau dapat dikatakan bahwa variabel financial leverage (DER), ROI, ROE, reputasi auditor dan reputasi underwriter secara bersama-sama berpengaruh terhadap underpricing.

Coefficients $^{3}$

\begin{tabular}{|c|c|c|c|c|c|}
\hline \multirow[b]{2}{*}{ Model } & \multicolumn{2}{|c|}{$\begin{array}{c}\text { Unstandardized } \\
\text { Coefficients }\end{array}$} & \multirow{2}{*}{$\begin{array}{c}\begin{array}{c}\text { Standardized } \\
\text { Coefficients }\end{array} \\
\text { Beta } \\
\end{array}$} & \multirow[b]{2}{*}{$\mathrm{t}$} & \multirow[b]{2}{*}{ Sid. } \\
\hline & $\mathrm{B}$ & Std. Error & & & \\
\hline 1 (Constant) & .624 & .096 & & 6.519 & .000 \\
\hline Reputasi_underwr & -.151 & .064 & -.289 & -2.365 & .021 \\
\hline Reputasi_auditor & -.110 & .061 & -.210 & -1.803 & .076 \\
\hline sqrt_DER & -.002 & .054 & -.007 & -.044 & .965 \\
\hline sqrt_ROE & -.259 & .320 & -.155 & -.807 & .422 \\
\hline sqrt_ROI & .312 & .462 & .131 & .676 & .501 \\
\hline
\end{tabular}

a. Dependent Variable: sqrt_Tingkatunderpricing

Sumber: Data diolah SPSS Berdasarkan tabel 4.13 dapat dilihat hasil analisis pengaruh variabel independen terhadap dependen secara parsial, namun berdasarkan data tersebut 4 variabel independen tidak berpengaruh secara parsial terhadap tingkat underpricing saham yaitu DER, ROI, ROE, dan Reputasi Auditor sedangkan Reputasi Underwriter berpengaruh secara siginifikan dan berarah negatif terhadap tingkat underpricing saham.

\section{Pembahasan}

Berdasarkan uji regresi linear berganda serta pengujian hipotesis diperoleh suatu pembuktian bahwa variabel financial leverage (DER), ROI, ROE, Reputasi Auditor, dan Reputasi Underwriter berpengaruh secara serentak (simultan) terhadap tingkat underpricing saham yang dibuktikan dengan hasil uji F-hitung sebesar 3,100 dengan tingkat signifikansi lebih kecil dari 0,05 yaitu sebesar 0,014. Sedangkan hasil pengujian secara parsial (Uji T) menunjukkan bahwa hanya variabel reputasi underwriter saja yang berpengaruh signifikan terhadap tingkat underpricing saham yang dibuktikan dengan uji parsial (Uji T) yang menunjukkan bahwa reputasi underwriter nilainya lebih kecil dari 0,05 (signifikan $<0,05$ ) sedangkan nilai financial leverage (DER), ROI, ROE, dan reputasi auditor lebih besar dari 0,05 (signifikan >0,05).
Tabel 4.11

Koefisien

Determinasi

Tabel 4.12

Hasil Uji F

Tabel 4.13

Hasil Uji T 


\section{Pengaruh Financial}

Leverage...

552

\section{KESIMPULAN}

Berdasarkan pembahasan hasil penelitian secara empiris yang telah diuraikan, maka diperoleh kesimpulan sebagai berikut:

1. Financial leverage tidak berpengaruh signifikan terhadap tingkat underpricing, karena sig $\mathrm{t}>$ a yaitu 0,965 .

2. Return on Investment (ROI) tidak berpengaruh signifikan terhadap tingkat underpricing, karena sig $\mathrm{t}>$ a yaitu 0,501. Profitabilitas yang besar sebagaimana yang disajikan di dalam prospektus belum tentu dapat menunjukkan kinerja perusahaan tersebut baik.

3. Return on Equity (ROE) tidak berpengaruh signifikan terhadap tingkat underpricing, karena sig $\mathrm{t}>$ a yaitu 0,422 .

4. Reputasi Auditor tidak berpemgaruh signifikan terhadap tingkat underpricing, karena sig t > a yaitu, 0,076. Reputasi auditor tidak menjadi pertimbangan investor yang melakukan investasi pada saham IPO karena kurangnya kepercayaan investor atas kualitas informasi keuangan yang disajikan dalam prospektus.

5. Reputasi Underwiter berpengaruh signifikan terhadap tingkat underpricing, karena sig $\mathrm{t}<\mathrm{a}$ yaitu, 0,021 dan berarah negatif. Semakin tinggi reputasi underwriter maka tingkat underpricing akan semakin rendah dan sebaliknya.

Keterbatasan penelitian ini hanya menggunakan 5 variabel, penelitian ini juga tidak berhasil membuktikan beberpa hipotesis yaitu financial leverage, ROI, ROE dan reputasi auditor. Saran untuk penelitian selanjutnya adalah yang pertama bagi investor yang berminat menanamkan modalnya di pasar modal harap memperhatikan faktor-faktor yang berpengaruh terhadap underpricing, yang kedua emiten dapat mempertimbangkan untuk menggunaka underwriter yang bereputasi tinggi, yang ketiga underwriter hendaknya meningkatkan kualitas pinjamannya.

\section{DAFTAR PUSTAKA}

Abdullah, Syukriy, 2000, Fenomena Underpricing Dalam Penawaran Saham Perdana (IPO) dan Faktor - Faktor Yang Mempengaruhinya, Jurnal Manajemen danBisnis, Vol 3, No 1, 65 - 83.

Ardiansyah, Misnen. 2003. "Pengaruh Variabel Keuangan Terhadap Return Awal dan Return 15 hari Setelah IPO serta Moderasi Besaran Perusahaan Terhadap Hubungan antara Variabel keuangan dengan Return Awal dan Return 15 Hari Setelah IPO di Bursa Efek Jakarta”. Jurnal Riset Akuntansi Indonesia Vol. 7, No 2, Mei. Hal 125-153.

Asnawi, Said Kelana dan Chandra Wijaya. 2005. Riset Keuangan PengujianPengujian Empiris. Jakarta : PT. Gramedia Pustaka Utama.

Daljono, (2000), Analisis Faktor - Faktor Yang mempengaruhi Initial Ruturn Saham Yang Listing Di BEJ (tahun 1990 - 1997), Simposium Nasional Akuntansi III, hal 556 -572.

Johnson. 2012. Analisis Faktor-Faktor yang Mempengaruhi Underpricing Harga Saham IPO Perusahaan yang Terdaftar di BEI.

Kristiantari, I Dewa Ayu. 2012. "Analisis Faktor-Faktor yang Mempengaruhi Underpricing Saham Pada Penawaran Saham Perdana di Bursa Efek Indonesia “(tesis).Universitas Udayana. 
Murdiyani. 2009. "Pengaruh Informasi Prospektus Perusahaan Terhadap Initial Return Pada Penawaran Saham Perdana (Studi pada perusahaan LQ-45 2001-2007)"(skripsi). Semarang : Universitas Diponegoro.

Sari, Ardhini Yuma. 2011. "Analisis Faktor-Faktor Yang Mempengaruhi Underpricing Pada Penawaran Umum Perdana "(skripsi).Semarang : Universitas Diponegoro.

http://eprints.undip.ac.id/29160/

Wahyuni, Tri. 2012. "Pengaruh Kondisi Keuangan dan Non Keuangan terhadap Tingkat Underpricing pada Penawaran Saham Perdana (IPO) di Perusahaan yang Listing di Bursa Efek Indonesia tahun 2008 - 2010 “.

Yasa, Gerianta Wirawan.2008."Penyebab Underpricing Pada Penawaran Saham Perdana di Bursa Efek Indonesia". Jurnal Akuntansi dan Bisnis, Vol 3 No. 2.

http://ojs.unud.ac.id/index.php/jiab/article/view/2590

Yolana, Chastina \& Dwi Martani (2005), Variabel - Variabel yang Mempengaruhi Fenomena Underpricing pada Penawaran Saham Perdana di BEJ tahun 1994 - 2001, Simposium Nasional Akuntansi VII Solo, 15 - 16 September 2005.p 538-540 
